\title{
Guns, Silences, and Change: Using Action Research in Contexts of Violence
}

\author{
Joanna Wheeler
}

Abstract Using participatory approaches within violent contexts calls for special attention to be paid to a range of issues and questions. Much of current development policy and practice does not take into account the degree to which violence can shift dynamics of power, identity, and affiliations, and therefore lead to radically different and sometimes negative outcomes from approaches that would be appropriate in other settings. This article argues that using action research in contexts of violence requires careful consideration of the following issues: the entry points for the research process; the way that risks are generated and experienced and the ethical implications of this; the differentiated experiences of violence and how these affect the action research process; and, the complexities of how violence affects the power/knowledge nexus. It describes some of the key steps taken in order to do action research in a situation where power is constantly shifting, and the practical implications of this analysis.

Using participatory approaches, in all their varieties, within violent contexts, calls for special attention to be paid to a range of issues and questions. These issues are not necessarily unique to contexts of violence, but the presence of violent conflict makes them more acute. Much of current development policy and practice does not take into account the degree to which violence can shift dynamics of power, identity, and affiliations, and therefore lead to radically different and sometimes negative outcomes from approaches that would be appropriate in other settings (Pearce et al. 2010). This article argues that using action research in contexts of violence requires careful consideration of the following issues: the entry points for the research process; the way that risks are generated and experienced and the ethical implications of this; the differentiated experiences of violence and how these affect the action research process; and, the complexities of how violence affects the power/knowledge nexus, particularly in terms of the types of knowledge generated through action research. This article will explore each of these issues as they emerged through a participatory action research process carried out in Rio de Janeiro, Brazil from 2006 to 2009, in order to reflect more generally on the implications of violence for action research. ${ }^{1}$ It will describe some of the key steps taken in order to do action research in a situation where power, manifest through violence and the threat of violence, is constantly shifting. And it will draw out practical implications for how to go about doing action research given this analysis.

\section{The context of Rio de Janeiro}

The next section provides some context for the action research project in Rio de Janeiro, focusing on the dynamics of social exclusion and violence as well as describing the main armed actors and the current policy environment around security. This description of context is important in order to situate the action research within the complexities generated through a context of violence. But the description of the context is also important in that it demonstrates why a careful power analysis of the different armed and violent actors and how they operate in contexts like these is necessary prior to the actual start of the research process. This deep understanding of the context helps to analyse and mitigate risks, and can also contribute to the decisions about how to approach the research, 
expose the implications of particular entrypoints. The next sections examine how this context of violence intervenes in the process of action research.

Rio de Janeiro, with just over 6 million residents, is one of the growing number of 'mega-cities' across the world, where large percentages of the population live in uncertain and poor conditions (Sassen 1994). The extreme spatialisation of inequality that currently characterises Rio de Janeiro is at least partly due to the history of how the city developed over the past century (Alvito and Zaluar 1998). The first favela, or illegal housing settlement, was created in the late 1800s by former slaves working at Rio's docks, who were evicted from tenement housing when the government razed the buildings. Since then, favelas have emerged on land considered inappropriate for commercial development at the time ${ }^{2}$ in response to the chronic lack of affordable housing. Currently, there are over 500 favelas (depending on how boundaries are drawn). Residents of favelas have not, until very recently, had formal access to electricity, sewerage, telephones, rubbish collection, street paving, etc. Despite over a hundred years of history, most favelas remain outside of the formal grid of urban services. Residents' associations formed in favelas normally took responsibility for managing informal infrastructure networks. The position of the state with respect to the favelas has tended towards malign neglect, with brief periods of hostility and aggression, and more recently, positive intervention.

Into this context of spatialised inequality and the unevenness of state capacity, violence has entered: driven by the drug trafficking trade and the state's violent response to it. Global demand for drugs and global flows of drugs and arms has helped to perpetuate the power of drug trafficking groups in Brazil (as elsewhere). The most lucrative markets in the USA and Europe are the main targets for the distribution network, although domestic markets across Latin America are growing. There is a strong incentive for local dealers to expand their own markets, as this is the only way to capitalise on their earnings - by selling or trading more drugs. This has, in part, fuelled the wars over territory between rival factions in Rio de Janeiro.

Parallel to this shift and expansion in the global market in drugs is the globalised arms trade. As
Brinceño-León and Zubillaga (2002) point out, it is the lethality of crime (rather than just the levels of crime) in Latin America that is striking. Whereas 63 per cent of all homicides worldwide are committed with firearms, in Latin America, the proportion exceeds 80 per cent. This is due to the readily available supply of arms: 'The recent spread of firearms in the region is linked in considerable measure to drug trafficking: the drug organisations have also engaged in illegal distribution of guns as part of their payments to local distributors' (Brinceño-León and Zubillaga 2002: 25). In Rio de Janeiro, the sophistication and power of weapons is also escalating. As I was told in one interview with a community researcher in Quitungo: 'Where before a young traficante [trafficker] would be happy with a pistol, now he wants an AK-47. Next they will have grenade launchers' (Alcir, community researcher, 5 May 2007).

The rise of the drug trade and the accompanying wars for control of the favelas contribute to an environment where the state is far from being the most powerful actor, and the ability of any part of the government to change this situation is limited. Since the 1980s most favelas have been dominated by drug trafficking gangs [traficantes], who have taken advantage of the dearth of state presence in favelas to establish a highly complex structure for the distribution and resale of drugs, primarily cocaine and marijuana. Prior to 2004, traficantes from one of three major factions controlled all but one favela in Rio de Janeiro. These factions often war with one another for control over lucrative drug sale and distribution points. In 2005, groups of men armed with police equipment began to invade and take control over favelas, expelling or killing those associated with the drug trafficking faction, and suppressing open drug trade (Bottari and Ramalho 2006b; Ramalho 2006; Torres 2006). These 'militias', as the media has labelled them, are made up of a mixture of off-duty, retired, or suspended police officers (military and civil), prison guards, firemen, and civilians. Within 18 months of taking over the first favela in 2004, the militias controlled nearly 171 communities across the city (Assembleia Legislativa do Estado do Rio de Janeiro 2008: 45). The militia retain close ties with the official police, often using weapons and vehicles from police depots for their 'operations', and communicating with the official police on a regular basis (Bottari and Ramalho 2006a; 
Assembleia Legislativa do Estado do Rio de Janeiro 2008). In most cases, the militia extort money from the community through a variety of means backed by threats of violence, from beatings and torture to execution (Assembleia Legislativa do Estado do Rio de Janeiro 2008: 44).

\section{Armed actors, the scale and scope of violence, and the state response}

Excluded groups in Rio de Janeiro are faced with extremes of insecurity and safety in favelas and other marginalised communities. The levels of insecurity and the pervasiveness of the effects of violence within these communities are juxtaposed with the relative safety and statecontrol in other parts of the city where many residents of favelas work. At the same time, across Brazil's cities, large parts of the middle class have retreated into fortified complexes, seeking to isolate themselves from the threat of violence and the social processes that seem beyond their control (Caldeira 1999). In conjunction with the increasing spatial stratification of security, there is a growing privatisation of security. Middleclass residents hire private security forces to protect their property and ensure their safety, while security in favelas is often both enforced and violated by trafficking groups.

With relatively high levels of violence in parts of Rio de Janeiro over a prolonged period of time, drug trafficking groups have become the dominant power in these communities. Between 2000 and 2006, 53,454 people were killed or disappeared by a combination of drug trafficking groups, the military police, and parastatal death squads (Rio de Paz 2007). Homicides have increased from nine per 100,000 in 1983 to 51 per 100,000 in 2002 (although this is as high as 90 per 100,000 in some regions of the city) (Iulianelli et al. 2004). The consequence of this violence is that

Cultural constructions of violence as normal have been maintained and transformed in a range of contemporary urban contexts, with the result that an increasingly complex web of institutions, groups and individuals is involved in the perpetration of everyday violence (Winton 2004: 169).

Those most likely to be involved, whether as a perpetrator or a victim of violence, are young men under the age of 21. According to Amnesty
International, men aged 15-24 are 30 times more likely than any other age group to die in homicide and 93 per cent of all homicide victims are male (Amnesty International 2005). According to the Brazilian Census (IBGE), the homicide rate in the state of Rio de Janeiro per 100,000 inhabitants for men aged 15-24 was 225 in 2004 and rose to 227 in 2005 . For boys aged 10-19 years, the rate is 97 per 100,000 (Costa 2006). At the same time, black people are twice as likely as people of other race to die (Amnesty International 2005).

Rising levels of violence are also situated in the context of the city and state governments' attempts at controlling the violence through repressive police action, growing levels of socioeconomic inequality in the city, and a public discourse in the media around the favelas as the primary source of criminality and violence in the city as a whole. Most recently, the pro-order perspective within the government has resulted in two new developments in security policy. The first is a so-called campaign of shock of order (Grudgings 2009), intended to involve the enforcement of laws at all levels of society (from parking restrictions to drink-driving to state control of the favelas). Related to this is the policy that is termed by the police as the occupation and pacification of favelas. Under a new coalition between the mayor and state governor, police forces are invading and then occupying a small number of favelas (Phillip 2010). The government has committed to spending US $\$ 3.5$ billion on this security policy (Amis 2010). The goal of these occupations is to institute permanent state control of the territory. The underlying assumption is that through using overwhelming force to subdue armed actors within the favela, and maintaining police presence there, it will eventually be possible for the state to institute other services. The long-term success of these policies is an open question.

The next section explains the approach I took to action research, given the context, and explores what difference violence makes to how action research unfolds.

\section{Description of research approach}

This section describes the research approach I took, and uses reflections on the experience of carrying out the research to draw out implications of working in a context of high levels of violence 
Image 1 Community researchers at participatory methods training, November 2006

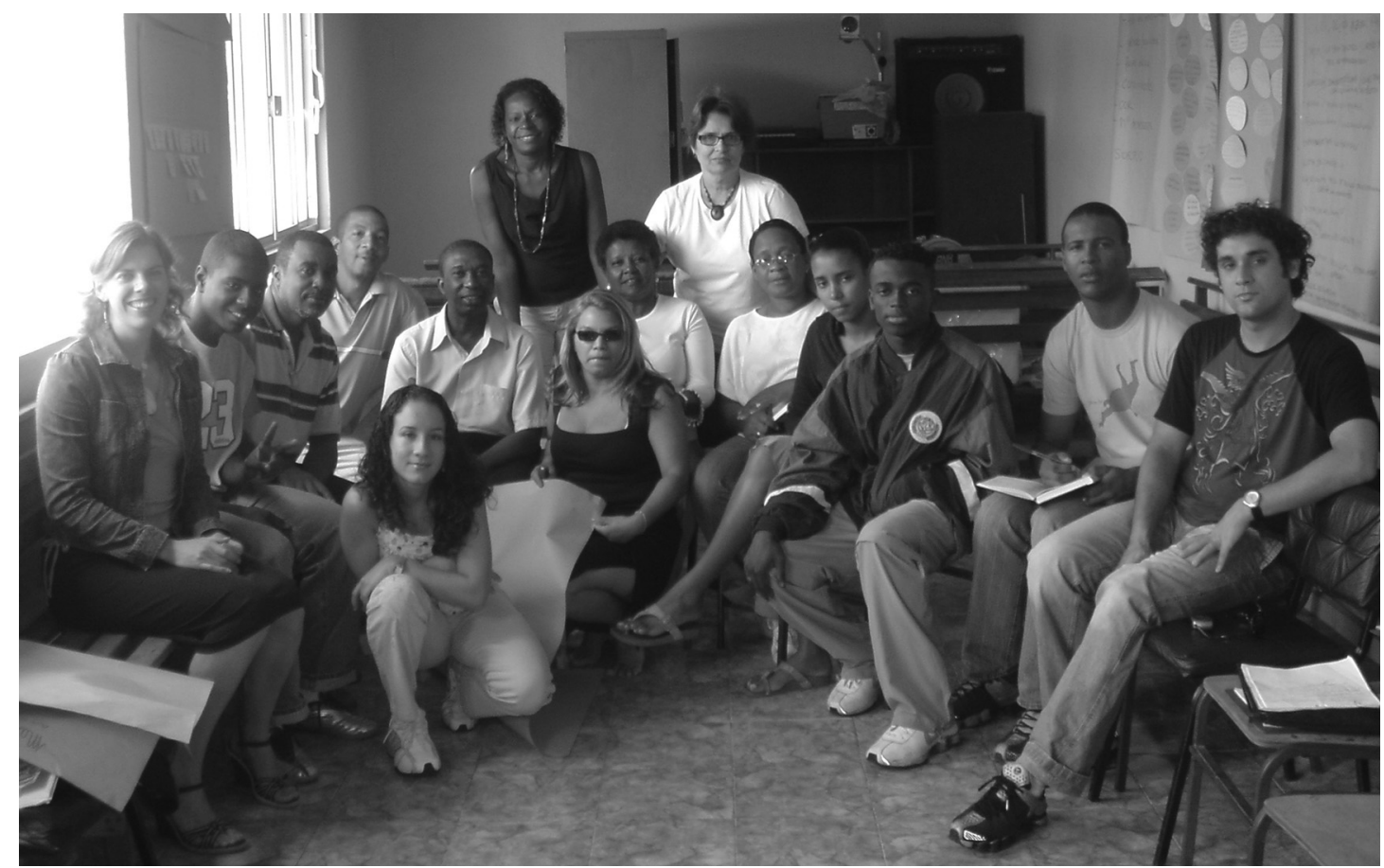

for action research. The research drew on elements of participatory action research and participatory learning and action, which treat research as a process that can create emancipatory knowledge by involving participants as active researchers (Park et al. 1993; Pretty et al. 1995; Reason and Bradbury 2001; Gaventa and Cornwall 2008). In particular, this research was designed to give the participants the opportunity for 'Collective self-reflective enquiry... in order to improve the rationality and justice of their own social... practices, as well as their understanding of these practices and the situations in which these practices are carried out' (Kemmis and McTaggart 1988: 1). In order to address these three foci of participatory action research (identifying practices, understanding these practices, and analysing the situations in which these practices are carried out), the research process facilitated public debate through participatory discussion groups in public spheres, connecting groups with different identities, including social class, gender, age, and social positioning (see Kemmis 2008). The methodology also integrated aspects of participatory urban appraisal (Moser and Holland 1997; Moser and McIlwaine 1999, 2004), and core elements of feminist methodologies, including attention to the intersection of race, gender and class, and issues of interpretation, translation and representation (Harding and Norberg 2003: 2011).

Building on this theoretical position, I worked with a group of community residents who became a core team of community researchers. I invited different leaders from the community to participate in a monthly meeting over a space of about five months to discuss some of the key issues in the research. These leaders were drawn from different segments of the community in terms of age, race, religious affiliation, political affiliation, and area of work within the community. Crucially, all were perceived as primarily neutral in relation to the armed groups relevant to the community. Many were leaders whom I had worked with previously on other research projects, so I had prior knowledge of their work, their profiles within the community and their interests. It also meant that there was a higher level of trust between them and me, and this trust would prove absolutely critical as the research unfolded. I tried to balance the selection of community researchers according to gender, age (ranging 16-65), sector of activity within the community (sport, drama, political party activist, social work, education, music). What was most important about this group was its capacity to mobilise different groups within 
the favela, which given the context, was not an easy task. So the community researchers, as leaders within the community, needed to have a certain degree of legitimacy in order to be able to take forward a participatory action research process. At the same time, the particular group of community researchers had their own biases that reflected their social positioning within the favela. It is important to recognise both aspects that community researchers enable the action research process in certain ways, and also bring in particular biases. Within a context of violence, both these aspects take on heightened importance.

The role of the community researchers was to be co-researchers with me, in the sense that they guided how the research questions were investigated, which groups within the community were most relevant and should be involved, and which tools were appropriate for particular sessions. We also undertook collective analysis of the research for them to identify for themselves what the most important implications of the research were for their own work as community leaders. Throughout the research process, we had numerous discussions about how the knowledge produced should be used, by whom and for what kinds of purposes. In recognition of the seriousness of this role and the commitment required during the most intensive period of the research, community researchers were paid a monthly salary for 20 hours' work per week from a grant that I received from the Development Research Centre on Citizenship, Participation and Accountability (Citizenship DRC). The steps taken during the research process included training for the community researchers, over 60 participatory discussion groups, a participatory video process, semi-structured interviews, a survey, and policy debates.

There are several reasons why this particular methodological approach was necessary. It was important from an ethical perspective both in terms of increasing the voices of people living in favelas about their situation, and in constructing a research process that gave participants as much control as possible. On the basis of my previous experience in the favelas, where I witnessed the suffering resulting from violence and the disenfranchisement and social exclusion that accompanied it, I undertook this research in part to try and encourage the space for democracy within this context. In that sense, I am not claiming to be a neutral observer in this process.

Aside from the ethical considerations, there was also a more pragmatic reason for choosing this methodological approach. Access to the favelas for in-depth research, especially on the topics of violence, is extremely limited. The difficulty of using surveys to research the micro-level dynamics of conflict is well documented (Justino et al. 2009). In fact, without strong relationships with residents in the community it is not possible to do any research there, as people would simply refuse to talk to you or you would be denied physical access to the community. This difficulty in carrying out in-depth empirical research in favelas leads to often superficial analysis of the situation. Because of a participatory action approach, working directly with community residents as researchers, this research had a unique kind of access to this environment, and generated empirical material that could not have been gained using any other methodology. This approach also influenced issues of power and knowledge, in terms of what kinds of knowledge were generated and who could make use of that knowledge. These issues are explored in greater depth in the sections below.

\section{Entry-points, access, and neutrality}

What are the right people or organisations to be entry-point(s) for action research in a context of violence? The entry-point can have a significant impact on how the research is perceived, how people relate to it and what kind of effects it can achieve. For example, within a context of violence, there is a central issue around the neutrality of the researchers in relation to the armed actors, and the degree to which the people in the communities involved perceive the research as affiliated to these armed actors. So while the community researchers involved in this process certainly brought their particular political and social biases to the project and are not neutral in those respects, what was more important was how they positioned themselves as neutral in relation to the armed actors controlling the favela.

Personal relationships are an important dimension to entry-points for research in contexts of violence because trust is crucial to research process (see Rodgers and Jones 2007). Therefore, a key issue to consider is the extent to 
which trust is generated or lost through any particular entry-point, and how this entry-point affects how people engage with the process (and the risks they are willing to take as a result). It can be very difficult to gain access to favelas, especially in light of control by militia and rapid changes in regimes of power. Most researchers gain access through an external organisation or part of the government. An entry-point via an official institution would have framed the research in a completely different light, in terms of perceptions of residents and participants in the research process, because this increases the expectations of research participants of what will be delivered through the research process. Entering via an external organisation also shapes the way that the research agenda unfolds and can shape the types of discussions possible through the research. I acted as an external researcher, but on the basis of long-established personal relationships with residents of the favela. My main entry-point in both field sites was prior relationships with people living within the favelas/neighbourhood. I have worked together with these people on two previous research projects from 1999 to 2003, as part of a larger research project on intergenerational social mobility and urban poverty; and as part of other research on citizenship and gender. I also used to live in one of the areas studied. There are risks associated with personal relationships as entrypoints, because they can be vulnerable to exploitation and manipulation, and because there is no obvious institution to give continuity to the processes instigated. So while these relationships meant certain aspects of the process were more possible (such as mobilising a group of community leaders to become community researchers, and convening a series of public dialogues), these relationships were also sensitive to the complex interplay of power within the favela and beyond.

The implications of the entry-point for the remainder of the action research process are significant. Violence has many implications for the nature of local patterns of authority that can directly implicate the research process through its entry-point. For example, the control of armed actors can shift unexpectedly as battles for territory break out, community-based organisations (both armed and unarmed) often have mercurial legitimacy, and violent contexts can often be characterised by a lack of trust in the state and formal institutions (including external non-governmental organisations) which are often associated with repressive violence by the police.

Irrespective of the particular entry-point, carrying out research in areas controlled by armed actors requires an ongoing process of negotiation along a series of different axes. Permission from these groups is essential in order to have access to communities that are dominated by non-state groups, yet independence from these groups is also fundamental to the integrity of the research and it was important to protect the independence of the research from these same groups. The implications of this system for the research project were clear: it was crucial that residents and participants in the research process did not perceive the community researchers to be affiliated with the militia or drug trafficking mafias, yet these violent actors needed to give their consent for the research to happen. In the end, this resulted in a complex process of negotiation to gain access while maintaining neutrality in relationship to the armed actors. ${ }^{3}$

At the outset of the research we made attempts to negotiate indirectly with the militia for permission to carry out the research. One of the community researchers spoke with the mother of a leader in the militia. Once we began the research, the community researchers felt we should have a more direct conversation, so I went with two of the researchers to officially introduce the project to the militia leaders and gained their approval. Approximately two weeks later, a meeting of the community researchers to plan some of the upcoming participatory discussion groups was invaded by five armed members of the militia. The brother of the head of the militia began an argument with one of the community researchers in the street and then the group of men followed her to the meeting. During this meeting, the militia members accused the researchers of having political motivations and forming cliques that did not work for the benefit of the community. The tone of the confrontation was aggressive on the part of the militia members, and a clear attempt at intimidation. Eventually the head of the militia appeared and agreed that the research could continue, but under the auspices of the militia. This meant holding meetings in a militiacontrolled building and including people chosen 
by the militia in the team of community researchers. When the militia members left the meeting, they sent a young woman who worked for them to sit at the meeting and take notes.

The community researchers were angry at this treatment, and felt that the militia was threatening the entire research project through an abuse of power. In the end, I met again with the head of the militia and his lieutenant and refused to agree to his demands. I emphasised the external connections of the research project as well as interest from the national media in the project as a means of increasing the safety of the researchers. The head of the militia wanted me to remove two of the researchers that he had prior disagreements with about unrelated issues. I refused to make any changes to the team of community researchers. He reluctantly agreed, but I think this is because he did not perceive the research as a threat to the militia's control of the favela. In the end, he agreed to the research continuing because he did not see any means to extort money from the project, and because he was clearly concerned that there would not be wider repercussions in the media if the militia were to interfere in the project. This was an example of how the micropolitics of the community, which are shaped by the context of violence, enter into the action research process, and how this also connects to the wider political context in which power is constantly contested by the armed actors involved. This example shows how the power relationships in a context of violence are constantly shifting, which implies that the negotiation process is also ongoing throughout the length of the research. As these processes of negotiation with armed actors demonstrate, the issue of physical access to conduct research is very problematic in this context. The community researchers were uniquely positioned to mobilise participants without creating untenable risk in relation to the armed actors. Nevertheless, there are clear risks associated with instigating a process of public dialogue that could directly or indirectly challenge the armed actors controlling particular areas. This issue of risk is addressed in the next section.

\section{Risks, fear and ethics}

This section will examine how risk is generated through the action research process and how experiences and perceptions of risk differ, in order to understand how risk influences action research in these settings. A conventional approach to action research does not always take into account the highly sensitive and politicised pathways of risk in violent contexts. Sometimes actions that would be totally innocuous in other contexts can be highly risky in violent ones. Participatory work in violent contexts should take account of risk, especially from the perspective of participants. Risk, in relation to participatory approaches, must also consider how the longerterm implications of the research might play out given shifts in dominant (violent) power-holders. In order to achieve access, both physically and in terms of the possibility to discuss these particular topics, this research methodology required an approach in which the community researchers acted as the primary arbiters of what constituted risk and how it should be managed. While there were certain kinds of risks that resulted from the particular context of violence, there were other kinds of risks related to the participatory process itself, and how it often surfaced deeply held emotions and experiences which were not easily addressed. Together, these different aspects of risk complicate the picture of how the ethics of participatory action research are navigated in a context of violence.

\subsection{Risk}

People involved in the participatory action research process experienced risk from the wider environment in a differentiated way, depending on the nature of their involvement, and their positionality within the community. For participants, there were risks that things that they said in a public discussion could cause negative consequences if armed actors learned of what they said, leading to violent reprisals or threats. The public nature of participatory research limits what people are able to say and also opens the possibility for profound reflection, and this is connected to a context of fear and mistrust caused by violence. Because of a history of frequent shifts in the violent control of the community, extreme caution is needed in what one says and to whom. This is a significant barrier to any kind of empirical research within contexts of violence, but it is more acute in a participatory action research process which is based on public dialogues. As one woman explained:

Before [when the drug traffickers were in control] we did not have freedom of expression, we couldn't have friendships. You 
never knew when one word that you said to someone on the street two kilometres from here might be taken the wrong way, reported back to the traficantes, and your life would be over (Field Diary, 10 December 2006).

For community researchers, there was a greater degree of risk, because as the example of the negotiation with the militia shows, the research process potentially entails direct confrontation between the community researchers and the armed actors. In other cases of leaders within the community, such confrontation led to expulsion, violent reprisal, or the closure of organisations (Field Diary 2007). For me, as an external researcher, it is difficult to gauge what level of risk I faced, because my own perception of risk varied during the research process. Partly my perception of risk was bound up with confronting my own biases about the dangers of violence in a highly violence-prone area (see Belousov et al. 2007; Lundy and McGovern 2008). Certain risks were predictable and thus to some extent manageable. Faced with the risk that the militia or drug trafficking faction would perceive the research as a threat and ban me from the community or harm me as a result, I sought to minimise it by working closely with community researchers and by carefully negotiating our access arrangements with traffickers and militia. A greater source of fear for me (as for those living in favelas) are the unpredictable risks: in my case, being caught up and accidentally shot in a gun battle between police, militia and drug trafficking factions; a change in which faction controlled the community, which necessitated suspension of the research; being robbed although this risk was probably greatest while I was in middle-class neighbourhoods or on public transportation.

The strategies we used to mitigate these risks included open discussion of the risks generated through the process, and collective agreement about how to manage them. This meant that the community researchers assessed risks from the wider environment constantly, and they decided what topics to discuss and how these discussions occurred. For example, during the production of the participatory video (The Life We Don't Want 2007), which directly examined the causes of violence and its potential solutions, participants made a film which dramatised the experience of a family as one of their children becomes drawn into violence. At no point in the film did they refer to the armed actors in the favela directly they treated the violence in an anonymous way, focusing instead on what happens within families when someone becomes involved (the response of the parents, other children, neighbours, etc.). This way of dealing with the subject minimised the risks that armed actors would seek to suppress the film because they were not directly implicated by it, but still allowed participants to bring out important dimensions of their experiences of violence. This example demonstrates how community researchers and participants are able to navigate the complicated terrain of what constitutes risk in a violent context. Their decision about how to frame the film was undoubtedly influenced by the fact that we also discussed how they would want to use the films that were made at the outset of the process, and participants identified 'influence the government' as a key objective of the films.

There were other practical steps that the community researchers and I took. Community researchers insisted on wearing official white t-shirts with the project logo, with matching identity badges that they created. They felt that this conferred a formality and officialdom to how they were perceived. The community researchers also identified people with links to the armed actors who could be brought into certain elements of the process. This was a way of reducing risk, because although they were not members of the armed groups, they had close family members involved in them. By opening up certain limited parts of the research process to them, they were ensuring that the armed actors would learn indirectly of what was happening, while the people bridging between the armed actors and the research could also warn us of rising tensions. In terms of my safety, it was important that there was a shared schedule that was known by all the community researchers in both sites where I was working. This meant that at least 20 people knew where I was supposed to be at any time.

Another dimension to the risk generated through a participatory action research project are the fears, sense of trauma, and deep suffering that can be surfaced through open discussions in a place where almost everyone has lost someone close to them through violence (see Nordstrom and Robben 1996; Alvarez et al. 1998). Violence 
leads to loss for many people who face it on a daily basis, and these experiences infuse the everyday, closing down certain spaces - particularly public spaces for dialogue. In that sense, an action research process is trying to reconstruct a safe space for dialogue in the face of these extreme pressures and emotions. At the same time, the discussions within these spaces can surface these experiences without necessarily offering a resolution for them. The creation of a safe space is closely related to the empathy that is needed on the part of the researchers engaged in this process, and the relationships that are built as the research unfolds.

While participatory action research methods can illicit powerful responses in terms of people's experiences of violence, the power of the method can also unwittingly contribute to a kind of voyeurism around violence. The fact that much of the detail around how violence affects people has the capacity to shock and horrify outside observers can distort an engagement with how that violence actually affects people (Hume 2007). So it is important not to reify particular acts of violence because of the fissure of horror they can cause, while at the same time acknowledging the depth of people's emotional responses to violence. This is a very delicate balance to strike throughout the research process, and often means that the data collection and extraction of conventional research methods must be subordinated to these wider ethical considerations.

\subsection{Ethics}

The nature of risk, then, has direct implications for the meaning of ethics in participatory action research. Participatory action research implies, in certain moments, the need to privilege the process of building up the trust and relationships sustained through the research process over more rigid forms of data collection and extraction. At the first women's group meeting in Quitungo, the women refused to discuss violence in community timeline (Field Diary, 18 January 2007).

Community researchers understood this as a result of the trauma many suffered from violence and a lack of confidence and trust in the space created through the research to relive these experiences. Later in the process, this same group of women went on to talk very openly about different aspects of their experience of violence, but as the external researcher, I needed to respect this process, rather than push for answers to the questions I wanted to ask. Similarly, throughout the participatory discussion groups, we approached the subject of violence often through oblique and tangential ways, because of the risks people felt about talking openly, especially given the potential for changes in the control of the armed group that could mean repercussions for speaking openly. A participatory action research process implies that the external researcher cedes control over how questions are addressed in large part to co-researchers from the community involved (Kemmis 2008). In a context of violence, these processes are even more sensitive and carry greater weight in terms of the risks involved for participants and researchers. Therefore there is a need to allow the slow, not always linear development, of a sense of collective identity around the research process to emerge.

Finally, there were also sensitivities about the actual knowledge that was produced through the process and how it would be used. For example, during one set of participatory discussions, participants produced social maps that identified locations of safety and danger in the community. The community researchers felt that this information was so sensitive that they did not want the copies of the maps kept in the community (as was done with all the other things produced through the research).

In sum, there are more general implications of the nature of risk within a violent setting for participatory action research. Risk assessment, as it is conventionally carried out, does not begin to address the highly contextualised and complex nature of risk in a violent context. These different kinds of risks have direct implications for the ethics of how participatory action research is conducted, which heighten the importance of privileging the development of relationships over time, and extreme sensitivity to the forms of knowledge being produced and how they can be used. The next section explores these issues further in terms of how specific groups within the favela were affected by violence.

\section{Social positioning and differentiated experiences of violence}

How does people's social positioning influence their experience of violence, and what difference does this make to a participatory approach? People's experience of violence is highly differentiated according to their social 
positioning. Categories of identity (gender, ethnicity, race, nationality, sexual orientation, age, disability, religion, etc.) can all influence how people experience violence, both as victims, perpetrators, and observers. These sorts of differences are important considerations for participatory approaches within these contexts.

The processes of socialisation in the favela include gender, family, and other categories of identity that add up to the complex web of interpersonal relationships that determine social positioning within the community (see Pearce 2006). Social positioning affects how people relate to armed actors (and to the research process). Understanding the dynamics of social positioning within the favela is difficult because it is affected by a large number of factors including gender, age, family structures and the broader relationships with the rest of the city. As Moncrieffe (2008: 16) explains, drawing on Jenkins (2004):

Identities are shaped by an internal-external dialectic, that is, through interaction between the individual and the collective. Jenkins argues that individuals are unique and variable, but selfhood is... constructed in the process of primary and subsequent socialisation, and in the ongoing interaction during which individuals define and redefine themselves and others throughout their lives.' Selfhood is not fixed... (Moncrieffe 2008: 16).

The various processes that socialise people generate identities that feed into violence that can also be linked to the actual spaces of socialisation (from the family, to the school, the neighbourhood, the city, and the state). Again, as Pearce argues:

... the categorisation of forms of violence must be complemented by a spatial analysis if we are to refine our understanding of how in practice these kinds of violence interact with gendered socialisation processes within each space. I would therefore start with the socialisation space of the home, move to the socialisation space of community, neighbourhood, school, to the socialisation space of associational life or civil society and finally to the socialisation space of nation state construction, whether as a finished or (as in many parts of the global South) incomplete and arguably unfinishable process, given the logic of globalisation. Gender socialisation is a variable in all these spaces, a likely transmitter mechanism for the reproduction and reinforcement of violence through all the spaces. This kind of analysis is open to empirical research... (Pearce 2006: 77).

The experience of violence is deeply embedded in people's biographies, in the history of community and continually reinforced through processes of social positioning. Relationships that are important at an individual level, including those within the family and with peers, can highlight the importance of what Gilligan terms horizontal axes of difference (Gilligan 2001). The effects of violence that operate at the level of individuals in the family cut across identity categories, including age, gender, race, and social class, and these horizontal divisions create significant obstacles for action research.

The action research process has to be sensitive to these differences, while simultaneously interrogating their meanings and interconnectivity. For example, some striking differences emerged between how groups of children and parents experienced violence. For the children involved, the fear that violence generated was almost overwhelming, particularly of their visions of what kinds of future they might have. Parents, on the other hand, often viewed children and young people as both dismissive of and responsible for the violence, failing to understand how seriously it affected them. There was a significant divergence between how children and parents thought violence affected them and what should be done in response. Many parents argued that it was the lack of adequate parenting that meant children got involved in violence, while children often pointed to the pressures parents were under to earn income for their families, which left them alone and without support apart from their friends. These different experiences of violence have implications for how the participatory action research process brings people together for public dialogue, and also for the kinds of action possible.

Another example of how social positioning affects how people experience violence was demonstrated through the creation of social maps of the community. Once participants 
created the maps, they added locations of relative safety and danger. Women, children, and elderly people drew these locations of safety and danger onto their own maps separately. The women identified the roofs of their houses as dangerous locations, and none of the other groups pointed this out. In the discussion of the maps, it emerged that women whose children were members of drug trafficking gangs were subject to the gangs hiding their weapons in the water cisterns on their roofs when they were fleeing the police or other gangs. Because one of their children was involved in the gang, the women were forced to remain silent about the weapons or risk their child facing punishment. But it in favelas, women usually hang their laundry to dry on their roof, so in hiding their weapons in the water cisterns, the roofs suddenly became locations of danger for the women, who were concerned with protecting their other children from stray gunshots, or discovering the guns. If the police were to discover the guns hidden there, they could accuse the women of involvement with the trafficking. This example demonstrates how social positioning within the favela affects how people experience violence.

The implications of these differentiated experiences of violence for the methodological approach include an awareness of where the boundaries of social positioning lie. This means that the process must be sensitive to these boundaries and the researchers must choose approaches that allow these different experiences to be heard and acknowledged, and interrogated. As such, the relationship between power and knowledge in terms of how people experience violence differently becomes crucial.

\section{Violence, power and knowledge}

What is the relationship between power and knowledge and how does violence or the threat of violence alter this? There is significant work showing the complex relationship between power and knowledge in development settings (Gaventa and Cornwall 2008; Brock and McGee 2002).

Violence can affect many dimensions of power, and therefore the relationship between power and knowledge becomes extraordinarily important in these contexts. For example, in a context of violence, there is also a high level of contingency of information: what people are willing to speak about, to whom, and why, are highly influenced by the way that violence can create fear, apathy, powerlessness and risk; and at the same time, violence can lead to a sense of power, entitlement and justice. This section examines the methodological implications of the influence of violence on the relationship between power and knowledge. In understanding how violence can lead to certain silences and gaps, it will also address how working through participatory action research in this context requires sensitivity to particular forms of knowledge, especially relational knowledge. Relational knowledge is defined as knowledge that is derived from how people interact with one another including emotions, sharing daily experiences, and exchanging actions within a particular context (Park et al. 1993).

This research process exposed the contingency of information within contexts of violence. In particular it emphasised how existing social relationships within the community and the relationships between the researcher and the researched informs and limits what kind of knowledge is generated. Both of these dimensions are important in understanding how participatory action research functions within a context of violence. Because this research occurred within a context of violence, it was subject to the same rules (established through the violent actors) that govern everyday life for people living in the communities involved, even as it tried to create a space where these can be subverted.

In terms of how violence affected the way that knowledge was shared through the research process, there were a series of push-and-pull factors that emerged. The social desirability effect, which is well documented in other forms of research, is a pull factor. People may often say something that they think the external researcher or others present want to hear. They may conform to social norms and values because this is seen as socially desirable. But within a violent context, there are also push factors affecting how people can speak publically and what kinds of knowledge have legitimacy. Violence and the threat of violence impinge on the ability to have an open dialogue and leads to the gaps and silences described by de Vries and Weber:

... although violence determines the structure of everyday life, of the individual and collective self, from within its very ground manifestation, and effects are often more elusive than can be grasped by cognitive or 
hermeneutical procedures for establishing and understanding reality. In that sense, violence - whether past or present, hidden or manifest, excessive or mitigated - can be said to impose a certain difficulty of articulation.

Its catastrophic and traumatic aspects call for more than moral indignation, theoretical cognition, or even aesthetic imagination. What seems to be required, in excess of these categories is a sensitivity to the indeterminate 'feelings', 'signs of history', 'ruins', and 'silences' for which no generally accepted or accessible idioms are ready to hand (de Vries and Weber 1997, cited in Pearce 2007: 18).

Experiences of violence can combine to create a kind of generalised sense of trauma. Beyond the direct effects of specific incidents of violence, there is a kind of miasma of violence that encompasses nearly everyone in the favela. This became very clear through the participatory research sessions, where many people became unable to speak because of the emotion overwhelming them (Pearce 2007). Some people were never able to speak about things that happened to them, such as during a session with elderly women who refused to talk about violence at all in their community timeline. They feared reliving the experiences of violence through speaking about them, and produced a community timeline that did not include a single incidence of violence over 30 years (Field Diary, 18 January 2007). In contrast, some, such as one woman during a session with parents, told a moving story about the violence she suffered from her husband, and the death of her son (22 November 2006). Everyone has experienced loss as a result of the violence, and the emotional effects of this cannot be underestimated. These discussions, in themselves, were often very difficult and painful, both for the participants and for me. It is not just the violent events themselves, but the way that these become embedded in people's personal histories and ways of being that will matter to the research process.

As such, the relational knowledge generated through an action research process is of paramount importance in a context of violence. In a setting of violence, the emotional dimension to violence that people have experienced can surface through the research process, and researchers need a way to address this. The strength of these emotions can lead to ethical problems with encouraging people to relive painful experiences (Hume 2007), as discussed in the section on risk and ethics.

Therefore, within an action research approach in the context of violence, there is a need to think carefully about how to recognise the roles that deeply embedded emotions and forms of relational knowledge play within the process. This could be in relation to the kind of trust that is required to create what is really considered to be a safe space for dialogue. But it could also be in relation to dealing with the emotions that surface through the process and the responses these can provoke. Partly for this reason, I incorporated the use of visual methods, including drama, photography, film, and drawing. These methods can allow participants to address difficult and painful topics in an oblique way, often through the use of fun and play (Rieber 1996). These methods can also be more apt at incorporating relational knowledge than conventional written and analytical methods. But also, an important dynamic of the relationship between power and knowledge in this context is to ensure that the process of participatory action research allows those involved to make sense for themselves out of what is done, and to use that knowledge in ways that are relevant for their lives. Due to the aspects of risk and the ethical implications of this, the way that social positioning affects people's experience of violence and the importance of relational knowledge, visual methods (such as participatory video) were often more appropriate than conventional methods.

\section{Conclusion}

This article has examined a range of issues that emerged through doing participatory action research in a context of violence, including the importance of entry-points that maintain neutrality in relation to armed actors; the nature of risk and the ethical considerations involved; the ways that violence influences the relationship between power and knowledge and the importance of relational knowledge in these contexts; and, the processes of socialisation that differentiate how people experience violence and therefore how they can engage in the research. These considerations are important in many contexts, but the nature of the effects of violence makes them much more acute, and has practical implications for how participatory action research 
is carried out. While this article has not been able to explore the considerable and complex outcomes of this research, it has shown the importance of the context of violence in shaping

\section{Notes}

1 In addition to the work in Rio de Janeiro, which is the primary basis for this article, it also draws on my experience as part of a research network working in a research group on violence, participation and citizenship from 2005 to 2010 (www.drc-citizenship.org); and my current research in the townships of Cape Town on xenophobic violence (in partnership with Laurence Piper and the University of Western Cape), and on citizen participation in Bosnia-Herzegovina (in collaboration with Tessa Lewin at the Institute of Development Studies and Snezana Misic from MDPi).

2 In many cases, land occupied and settled as a favela later became highly valued real estate.

\section{References}

Alvarez, S.; Dagnino, E. and Escobar, A. (1998) Cultures of Politics/Politics of Culture: Re-visioning Latin American Social Movements, Boulder CO: Westview Press

Alvito, M. and Zaluar, A. (1998) Um Século de Favela, Rio de Janeiro: Fundacao Getulio Vargas

Amis, Louis (2010) 'Crime: The Problem of Violence no Longer seems Intractable', Financial Times, 14 November, London, www.ft.com/cms/s/0/6f2f7190-edfe-1 1df-861600144feab49a.html\#ixzz1TOY8yHsu (accessed 27 July 2011)

Amnesty International (2005) Brazil: 'They Come in Shooting': Policing Socially Excluded Communities, London: Amnesty International

Assembleia Legislativa do Estado do Rio de Janeiro (2008) Relatório Final Da Commisão Parlamentar de Inquérito Destinada a Investigar a Ação de Milicías no Ámbito do Estado do Rio de Janeiro, Rio de Janeiro: Assembleia Legislativa do Estado do Rio de Janeiro: 282

Belousov, K.; Horlick-Jones, T.; Bloor, M.; Gillinskiy, Y.; Golbert, V.; Levi, M. and Pentsov, D. (2007) 'Any Port in a Storm: Fieldwork Difficulties in Dangerous and Crisis-ridden Settings', Qualitative Research 7.2: 155-75

Bottari, E. and Ramalho, S. (2006a) 'Milicías Avançam pelo Corredor do Pan 2007', O Globo, Rio de Janeiro: 22

Bottari, E. and Ramalho, S. (2006b) 'Proteção Imposta: Milícias Ameaçam Moradores de how people engage with the research process. As such, it offers some insight into both the possibilities and obstacles of using action research as a methodology in a context of violence.

During the military dictatorship a number of favelas on prime land in the Zona Sul were razed and the residents resettled into distant housing estates. As the city has grown, many of these housing estates have now become part of the more central part of the city. New favelas are emerging in parallel to the expansion of the city itself to the west, as new developments for the middle class bring a demand for civil construction workers, and other menial jobs.

3 Neutrality is a particularly important feature of researching violence in cases where paramilitary or parapolice forces have control (Feenan 2002).

Favelas que se Recusam a Pagar taxas de Proteção', $O$ Globo, Rio de Janeiro: 10

Brinceño-León, Roberto and Zubillaga, Veronica (2002) 'Violence and Globalisation in Latin America', Current Sociology 50.1: 19-37

Brock, K. and McGee, R. (2002) Knowing Poverty: Critical Reflections on Participatory Research and Policy, London: Earthscan

Caldeira, T. (1999) 'Fortified Enclaves: The New Urban Segregation', in James Holston, Cities and Citizenship, Durham: Duke University Press

Costa, C. (2006) 'Pesquisa: Violência é o Maior Problema do Rio', O Globo, Rio de Janeiro: 29 de Vries, H. and Weber, S. (eds) (1997) Violence, Identity, and Self-Determination, Palo Alto CA: Stanford University Press

Feenan, D. (2002) 'Researching Paramilitary Violence in Northern Ireland', International Journal of Social Research Methodology 5.2: 147-63

Gaventa, J. and Cornwall, A. (2008) 'Power and Knowledge', in Peter Reason and Hilary Bradbury, The Sage Handbook of Action Research: Participative Inquiry and Practice, 2nd edition, London: Sage

Gilligan, J. (2001) Preventing Violence, New York: Thames and Hudson

Grudgings, S. (2009) 'Rio's Unruly Beaches Taste "Shock of Order", Reuters, Rio de Janeiro, www.reuters.com/article/2009/12/16/us-riobeaches-idUSTRE5BF40B20091216 (accessed 28 February 2012) 
Harding, S. and Norberg, K. (2003) 'New Feminist Approaches to Social Science Methodologies: An Introduction', Signs 30.4: 2009-15

Hume, M. (2007) 'Unpicking the Threads: Emotion as Central to the Theory and Practice of Researching Violence', Women's Studies International Forum 30: 147-57

Iulianelli, J.; Guanabara, L.; Pontes Fraga, P. and Blickman, T. (2004) A Pointless War: Drugs and Violence in Brazil, Amsterdam: Transnational Institute

Jenkins, R. (2004) Social Identity, London: Routledge

Justino, P.; Leavy, J. and Valli, E. (2009) 'Quantitative Methods in Contexts of Everyday Violence', IDS Bulletin 40.3: 41-9

Kemmis, S. (2008) 'Critical Theory and Participatory Action Research', in Peter Reason and Hilary Bradbury, The Sage Handbook of Action Research: Participative Inquiry and Practice, 2nd edition, London: Sage

Kemmis, S. and McTaggart, R. (1988) The Action Research Planner, Geelong, Victoria: Deakin University Press

Lundy, P. and McGovern, M. (2008) 'The Ethics of Silence: Action Research, Community Truth-telling and Post-conflict Transition in the North of Ireland', Action Research 4.1: 49-64

Moncrieffe, Joy (2008) Making and Unmaking the Young Shotta [Shooter]: Boundaries and (Counter)Actions in the 'Garrisons', IDS Working Paper 297, Brighton: IDS

Moser, C. and Holland, J. (1997) Urban Poverty and Violence in Jamaica, Washington DC: World Bank

Moser, C. and McIlwaine, C. (2004) Encounters with Daily Violence in Latin America: Urban Poor Perceptions from Colombia and Guatemala, New York: Routledge

Moser, C. and McIlwaine, C. (1999) 'Participatory Urban Appraisal and its Application for Research on Violence', Environment and Urbanisation 11.2: 203-26

Nordstrom, C. and Robben, A. (eds) (1996) Fieldwork Under Fire: Contemporary Studies of Violence and Survival, Berkeley CA: University of California

Park, P.; Brydon-Miller, M.; Hall, B. and Jackson,T. (eds) (1993) Voices of Change: Participatory Research in the United States and Canada, Westport CT: OISE Press
Pearce, J. (2007) Violence, Power and Participation: Building Citizenship in Contexts of Chronic Violence, Brighton: IDS

Pearce, J. (2006) 'Bringing Violence "Back Home": Gender Socialisation and the Transmission of Violence through Space and Time', in Marlies Glasius, Mary Kaldor and Helmut Anheier, Global Civil Soceity Handbook 2006/2007, London: Sage

Pearce, J.; McGee, R. and Wheeler, J. (2010) Violence, Security and Democracy: Perverse Interfaces and their Implications for States and Citizens in the Global South, IDS Working Paper 357, Brighton: IDS

Phillip, Tom (2010) 'Rio de Janeiro Police Occupy Slums as City Fights Back against Drug Gangs', The Guardian, 12 April, London, www.guardian.co.uk/world/2010/apr/12/ rio-de-janeiro-police-occupy-slums (accessed 5 December 2010)

Pretty, J.; Gujit, I.; Scoones, I. and Thompson, J. (1995) A Trainer's Guide for Participatory Learning and Action, London: International Institute for Environment and Development (IIED)

Ramalho, S. (2006) 'Milicías Estendem Atividades a Grilagem de Terra', O Globo, Rio de Janeiro: 27

Reason, P. and Bradbury, H. (eds) (2001) The Sage Handbook of Action Research: Participative Inquiry and Practice, London: Sage

Rieber, Lloyd P. (1996) 'Seriously Considering Play: Designing Interactive Learning Environments based on the Blending of Microworlds, Simulations, and Games', Educational Technology Research and Development 44.2: 43-58

Rio de Paz (2007) A Violência No Estado de Rio de Janeiro, Rio de Janeiro, www.riodepaz.org.br/ home.html (accessed 28 January 2012)

Rodgers, D. and Jones, G. (2007) 'Researching Youth and Violence in Central America: Participatory Methodologies', Bulletin of Latin American Research 26.4

Sassen, S. (1994) The Global City: London, New York, Tokyo, Princeton: Princeton University Press

Torres, S. (2006) 'Milícia de Policias Assedia area Nobre do Rio', Folha de São Paulo, São Paulo: C4

Winton, A. (2004) 'Urban Violence: A Guide to the Literature', Environment and Urbanisation 16.2: 165-84 